\title{
A Soluble, Folded Protein without Charged Amino Acid Residues
}

Højgaard, Casper; Kofoed, Christian; Espersen, Roall; Johansson, Kristoffer Enøe; Villa, Mara; Willemoes, Martin; Lindorff-Larsen, Kresten; Teilum, Kaare; Winther, Jakob R.

\section{Published in:}

Biochemistry

Link to article, DOI:

10.1021/acs.biochem.6b00269

Publication date:

2016

Document Version

Publisher's PDF, also known as Version of record

Link back to DTU Orbit

Citation $(A P A)$ :

Højgaard, C., Kofoed, C., Espersen, R., Johansson, K. E., Villa, M., Willemoes, M., Lindorff-Larsen, K., Teilum, K., \& Winther, J. R. (2016). A Soluble, Folded Protein without Charged Amino Acid Residues. Biochemistry, 55(28), 3949-3956. https://doi.org/10.1021/acs.biochem.6b00269

\section{General rights}

Copyright and moral rights for the publications made accessible in the public portal are retained by the authors and/or other copyright owners and it is a condition of accessing publications that users recognise and abide by the legal requirements associated with these rights.

- Users may download and print one copy of any publication from the public portal for the purpose of private study or research.

- You may not further distribute the material or use it for any profit-making activity or commercial gain

- You may freely distribute the URL identifying the publication in the public portal 


\title{
A Soluble, Folded Protein without Charged Amino Acid Residues
}

\author{
Casper Højgaard, Christian Kofoed, ${ }^{\dagger}$ Roall Espersen, ${ }^{\ddagger}$ Kristoffer Enøe Johansson, ${ }^{\S}$ Mara Villa, ${ }^{\prime}$ \\ Martin Willemoës, Kresten Lindorff-Larsen, Kaare Teilum, and Jakob R. Winther* \\ Linderstrøm-Lang Centre for Protein Science, Department of Biology, University of Copenhagen, DK-2200 Copenhagen N, \\ Denmark
}

\section{Supporting Information}

ABSTRACT: Charges are considered an integral part of protein structure and function, enhancing solubility and providing specificity in molecular interactions. We wished to investigate whether charged amino acids are indeed required for protein biogenesis and whether a protein completely free of titratable side chains can maintain solubility, stability, and function. As a model, we used a cellulose-binding domain from Cellulomonas fimi, which, among proteins of more than 100 amino acids, presently is the least charged in the Protein Data Bank, with a total of only four titratable residues. We find that

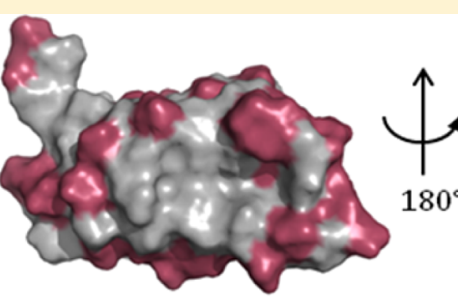

= hydroxy and amide residues the protein shows a surprising resilience toward extremes of $\mathrm{pH}$, demonstrating stability and function (cellulose binding) in the $\mathrm{pH}$ range from 2 to 11 . To ask whether the four charged residues present were required for these properties of this protein, we altered them to nontitratable ones. Remarkably, this chargeless protein is produced reasonably well in Escherichia coli, retains its stable three-dimensional structure, and is still capable of strong cellulose binding. To further deprive this protein of charges, we removed the $\mathrm{N}$-terminal charge by acetylation and studied the protein at $\mathrm{pH} 2$, where the $\mathrm{C}$-terminus is effectively protonated. Under these conditions, the protein retains its function and proved to be both soluble and have a reversible folding-unfolding transition. To the best of our knowledge, this is the first time a soluble, functional protein with no titratable side chains has been produced.

$\mathrm{C}$

harge is one of the fundamental properties thought to be

required for proper folding and function of proteins, and protein charges are considered to be crucial for protein solubility. Seven different amino acid residues (Asp, Glu, Arg, Lys, His, Cys, and Tyr) have titratable side chains in a $\mathrm{pH}$ interval from 2 to 12 . Of these, the first five are typically categorized as the charged residues ${ }^{a}$, because they are usually found in an ionized state near neutral $\mathrm{pH}$. In an average, soluble protein, Asp, Glu, Arg, Lys, and His together comprise 25\% by number. ${ }^{b}$ In accordance with their high prevalence, it is generally accepted that surface charges provide a means for specificity and topological orientation of surface interactions in proteins. $^{1,2}$ At the same time, charge-charge interactions are generally regarded as being important to protein solubility by inducing long-range repulsion between alike-charged species. This has been clearly demonstrated by introduction of charged side chains on a massive scale, termed "supercharging", and has, albeit at a cost of thermodynamic stability, in several instances been shown to provide an increased resilience toward aggregation, particularly at elevated temperatures. ${ }^{3-5}$ In line with this observation, thermo-stable proteins, in general, contain more surface charges than their mesophilic counterparts. $^{6-8}$ Neutralization of surface charges is suggested to be required for efficient amyloid fibril formation, ${ }^{9}$ and chemical and mutational neutralization of charges has indeed been shown to promote the rate of fibrillation. ${ }^{10-12}$
A better understanding of how surface charges affect protein solubility and aggregation rates has many important medical and industrial applications. ${ }^{13}$ It has been shown that charged amino acids contribute favorably to solubility in a $\mathrm{pH}$ - and context-dependent manner. ${ }^{14,15}$ However, the solubility of native proteins appears to correlate only with the fraction of the accessible surface area that is negatively charged, not with the fraction that is positively charged. ${ }^{16}$ This has been suggested to be due to weak hydration of arginine and lysine residues. ${ }^{14,17}$

The effects of salt bridges on protein stability have been studied using double-mutant cycles, ${ }^{18}$ and although the significance of naturally occurring salt bridges remains controversial, ${ }^{19,20}$ stabilization through protein engineering has been reported. ${ }^{21,22}$ In any case, the stabilizing effects of individual salt bridges are highly context-dependent, as they depend on the accessible surface area of the salt bridge, ${ }^{23}$ longrange charge-charge interactions with the rest of the protein, ${ }^{24}$ and the specific geometry of residues involved. ${ }^{25}$ In addition to local interactions such as salt bridges, Coulombic interactions between charged residues distinguish themselves by being able to act over relatively long distances. Thus, a change in the charge state of one residue, when titrated, may influence many other titratable residues, resulting in a complex overall titration

Received: March 24, 2016

Revised: June 3, 2016

Published: June 16, 2016 
resulting in the final chargeless variant presented here, EXG:CBM ${ }^{\mathrm{MQMW}}$.

Expression and Purification. Protein was prepared as described elsewhere, ${ }^{37}$ although EXG:CBM ${ }^{\mathrm{MQMW}}$ eluted from Avicel (Sigma-Aldrich) at a lower temperature $\left(68-75{ }^{\circ} \mathrm{C}\right.$ ). The yield of EXG:CBM ${ }^{\mathrm{MQMW}}$ after the final purification $(\sim 2$ $\mathrm{mg} / \mathrm{L})$ was also substantially lower than that of EXG:CBM (20 $\mathrm{mg} / \mathrm{L}$ ) in part because of a decreased resistance to lyophilization. Acetylation of EXG:CBM ${ }^{\mathrm{MQMW}}$ was achieved by adding a 100-fold molar access of acetic anhydride followed by chromatography on a Superdex 75 column. Complete acetylation was confirmed by mass spectrometry.

Cellulose Binding Assay. Two micrograms of each EXG:CBM variant ( $4 \mu \mathrm{g}$ of acEXG:CBM $\left.{ }^{\mathrm{MQMW}}\right)$ and $2 \mu \mathrm{g}$ of ribonucelase A (GE Healthcare) were diluted into $50 \mathrm{mM}$ sodium phosphate buffer at the appropriate $\mathrm{pH}$, and $1 \mathrm{mg}$ of Avicel was added. The samples were incubated for $1 \mathrm{~h}$ at $4{ }^{\circ} \mathrm{C}$, followed by centrifugation ( $5 \mathrm{~min}$ at $16000 \mathrm{~g}$ ). Supernatants were transferred to new Eppendorf tubes, and the cellulose pellets were washed twice with buffer. Supernatants and control samples without Avicel were precipitated by adding TCA to a final concentration of $12 \%$. Cellulose and TCA pellets were resuspended directly in sample buffer and used for Tricinesodium dodecyl sulfate-polyacrylamide gel electrophoresis (Tricine-SDS-PAGE) as described previously. ${ }^{38}$

Solubility Measurements. For measurements of precipitation propensity, lyophilized protein was suspended in $10 \mathrm{mM}$ sodium phosphate buffer at the appropriate $\mathrm{pH}$ and monitored after centrifugation for $20 \mathrm{~min}$ at $20000 \mathrm{~g}$ followed by measurement of the absorbance at $280 \mathrm{~nm}$ on a NanoDrop ND-1000 spectrophotometer. Samples were left at room temperature between measurements. Extinction coefficients from ExPASy ProtParam ${ }^{39}$ were used to convert absorbance to protein concentration. The solubility in ammonium sulfate was measured as described previously. ${ }^{14}$ All measurements were taken in triplicate.

Stability Measurements. Guanidine-induced unfolding was monitored via fluorescence spectroscopy using a PerkinElmer LS55 luminescence spectrometer. The samples $[\sim 0.3 \mu \mathrm{M}$ protein with an appropriate amount of $\mathrm{GdnHCl}$ in $50 \mathrm{mM}$ glycine ( $\mathrm{pH} 2.6$ ) or $50 \mathrm{mM}$ MOPS ( $\mathrm{pH} 7.0)]$ were excited at $280 \mathrm{~nm}$, and the intensity of the emission at $350 \mathrm{~nm}$ was measured. All measurements were taken at $25{ }^{\circ} \mathrm{C}$. Data were fitted using the linear-extrapolation method. ${ }^{56}$ The signal did not change significantly between 1 and $24 \mathrm{~h}$ after mixing the samples, so $1 \mathrm{~h}$ was chosen for equilibration.

Circular Dichroism (CD). Changes in the secondary and tertiary structure as a response to $\mathrm{pH}$ were followed using $\mathrm{CD}$ signals in the far- and near-UV area (190-260 and 250-340 $\mathrm{nm}$, respectively) with a J-810 Jasco spectropolarimeter. The proteins $(10-50 \mu \mathrm{M})$ were diluted in $10 \mathrm{mM}$ potassium phosphate buffer at the appropriate $\mathrm{pH}$. All measurements were performed at $25{ }^{\circ} \mathrm{C}$. Each spectrum shown is an average of 10 (far-UV) or 5 (near-UV) spectra.

NMR Spectroscopy. Cultures were grown in MOPS medium with ${ }^{15} \mathrm{NH}_{4} \mathrm{Cl}$ (98\%, Sigma-Aldrich) as the nitrogen source. The proteins were expressed and purified with Avicel as for the unlabeled protein. The protein was dissolved in $90 \mathrm{mM}$ $\mathrm{KCl}, 10 \% \mathrm{D}_{2} \mathrm{O}, 1 \mathrm{mM}$ 4,4-dimethyl-4-silapentane-1-sulfonic acid (DSS), and $0.02 \% \mathrm{NaN}_{3}$ to a final concentration of $\sim 1.1$ $\mathrm{mM}$ (EXG:CBM) or $\sim 0.3 \mathrm{mM}$ (EXG: $\mathrm{CBM}^{\mathrm{MQMW}}$ ). Protein solutions were brought to the starting $\mathrm{pH}$ and titrated with either $\mathrm{NaOH}$ (EXG:CBM) or $\mathrm{HCl}\left(\mathrm{EXG}: \mathrm{CBM}^{\mathrm{MQMW}}\right)$. The
$\mathrm{pH}$ of the sample was determined before and after each NMR measurement and was generally in good agreement $(<0.1 \mathrm{pH})$. Measurements were taken in Shigemi tubes on a $750 \mathrm{MHz}$ (EXG:CBM) or $800 \mathrm{MHz}$ (EXG:CBM ${ }^{\mathrm{MQMW}}$ ) Varian Inova spectrometer at $25{ }^{\circ} \mathrm{C}$. The Varian BioPack gNhsqc.c pulse sequence was used for HSQC experiments and the sofastNhmqc.c pulse sequence for HMQC experiments. $\mathrm{p} K_{\mathrm{a}}$ values were obtained by calculating a weighted chemical shift change from the proton $\left(\Delta \mathrm{H}^{1}\right)$ and nitrogen $\left(\Delta \mathrm{N}^{15}\right)$ chemical shifts of each backbone amide using ${ }^{40}$

$$
W \Delta \delta=\sqrt{\left(\Delta \mathrm{H}^{1}\right)^{2}+\left(0.154 \Delta \mathrm{N}^{15}\right)^{2}}
$$

and fitting to the Henderson-Hasselbalch equation of the form

$$
W \Delta \delta=\frac{W \delta_{\mathrm{A}} 10^{\mathrm{pH}-\mathrm{p} K_{\mathrm{a}}}+W \delta_{\mathrm{AH}}}{1+10^{\mathrm{pH}-\mathrm{p} K_{\mathrm{a}}}}
$$

Only strong, unambiguous assigned chemical shifts were used for the calculation (resulting in different cutoffs in the basic region of the $\mathrm{pH}$ scale for the different residues), and only signals with significant changes $\left(W \Delta \delta_{\max } \geq 0.1\right)$ were considered. The $\mathrm{pK}$ a values of the C-terminus and Asp36 were determined directly from their respective amid signals. Because of line broading and loss of the His 90 amid signal, the $\mathrm{p} K_{\mathrm{a}}$ value of His 90 was determined from a global fit of nine of the spatially closest residues (S46, G47, Q48, Q49, G88, S89, Thr91, Thr93, and Ala95).

\section{RESULTS AND DISCUSSION}

Design of a Charge-Free Protein. To identify a lowcharge protein with a known well-defined tertiary structure, we searched the Protein Data Bank (PDB) for a soluble protein of $>100$ residues that has the smallest number of titratable residues. Using this method, we identified a cellulose-binding domain from Cellulomonas fimi, xylanase B (PDB entry $\left.1 \mathrm{EXG}^{41}\right)$, with only four residues of 110 being charged, $\mathrm{K} 28$, D36, R68, and H90 (Figure 1). Three of these four charged residues are fully solvent exposed, while $\mathrm{H} 90$ is only slightly accessible ( $14 \%$ calculated with GETAREA $\left.{ }^{42}\right)$. None are located at the cellulose-binding site. ${ }^{43}$ To assess whether some of the charged residues might be essential for structure or function, we aligned the sequence with homologous protein domains from the NCBI database. This indicated that none of the four charges were conserved (Figure S1).

The all- $\beta 3 \mathrm{D}$ structure of this protein domain, which we term EXG:CBM, appears to be quite conventional with a welldefined hydrophobic core, and a disulfide bond, but without any tyrosine or free cysteine residues (which are also titratable). Interestingly, however, the protein surface is dominated by hydroxyl amino acids rather than charged side chains. ${ }^{41}$ In addition, it is of practical relevance that tight binding to cellulose provides a simple assay for function as well as a method of purification. ${ }^{44}$

Several noncharged substitutions of the four charged residues were chosen on the basis of the predicted changes in the free energy of unfolding (calculated by FoldX ${ }^{36}$ ) and assessed experimentally (see Experimental Procedures). The mutant variant presented here, EXG:CBM ${ }^{\mathrm{MQMW}}$, carries the $\mathrm{K} 28 \mathrm{M}$, D36Q R68M, and H90W mutations. Further chemical modification of the $\mathrm{N}$-terminus using an acetylation reagent yielded a protein ( $\mathrm{acEXG}: \mathrm{CBM}^{\mathrm{MQMW}}$ ) that is entirely free of ionic charges at low $\mathrm{pH}$ (Figure 1). 
Expression of EXG:CBM ${ }^{\mathrm{MQMW}}$ in E. coli yielded approximately $8 \mathrm{mg}$ of protein/L of culture. It should also be mentioned that EXG:CBM is part of a secreted protein with a single disulfide bond, and production in E. coli takes place via secretion into the periplasm. Whether the chaperone ensemble in the periplasm is more suited to deal with proteins with fewer charges, than the chaperones in the cytosol, is unknown.

EXG:CBM Remains Functional Despite Charge Depletion and Extreme pH Values. The binding of EXG:CBM to microcrystalline cellulose (Avicel) is strong $\left(K_{\mathrm{d}} \approx 10^{-6} \mathrm{M}^{43,45}\right)$, and on this basis, we have developed a purification protocol, ${ }^{37}$ which includes a combination of batch coupling and elution from cellulose with hot distilled water $\left(75-80{ }^{\circ} \mathrm{C}\right)$ followed by chromatography on Superdex 75. Following each step, pooled fractions were concentrated by lyophilization. This procedure was also implemented for the mutant protein, although the temperature at which the mutant protein was eluted from cellulose was somewhat lower $\left(68-75^{\circ} \mathrm{C}\right)$.

To assess the functionality of the EXG:CBM variants in a broad $\mathrm{pH}$ range, the proteins were dissolved in phosphate

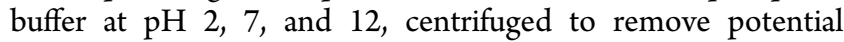
precipitation, and transferred to a new tube to which cellulose was added and collected after incubation for $1 \mathrm{~h}$. EXG:CBM, EXG:CBM ${ }^{\mathrm{MQMW}}$, and acEXG:CBM ${ }^{\mathrm{MQMW}}$ retained their binding to the cellulose under all $\mathrm{pH}$ conditions, resulting in complete pull down (Figure 2). These results are in agreement

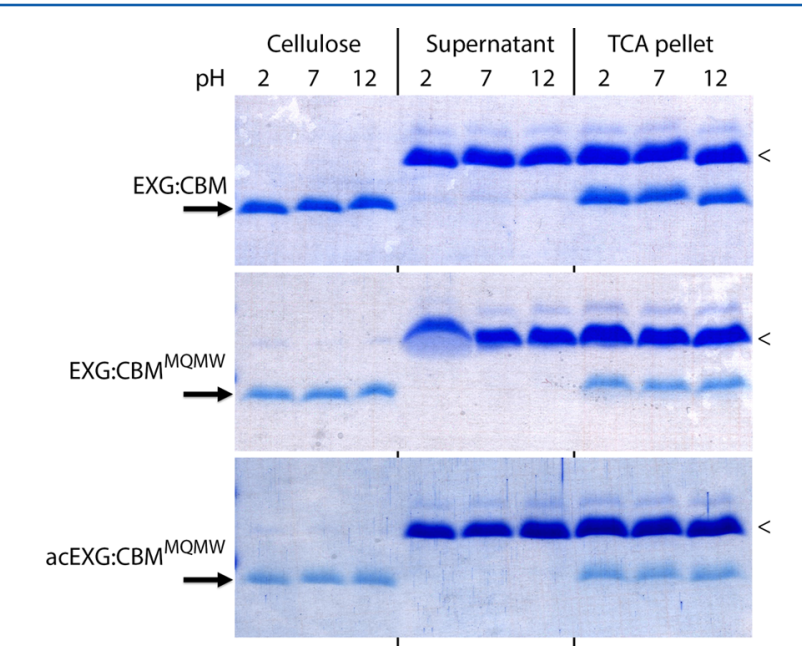

Figure 2. Cellulose binding assay. The indicated EXG:CBM protein variants and ribonuclease A (included as a loading control) were incubated with Avicel for $1 \mathrm{~h}$ followed by centrifugation to precipitate functional EXG:CBM bound to cellulose. "Cellulose" and "Supernatant" fractions were subjected to Tricine-SDS-PAGE. "TCA pellet" refers to TCA pellets from control samples without Avicel but otherwise treated in the same manner. The arrows indicate the position of EXG:CBM bands $(2 \mu \mathrm{g}$ per lane for EXG:CBM and EXG: $\mathrm{CBM}^{\mathrm{MQMW}}$ and $4 \mu \mathrm{g}$ per lane for acEXG: $\mathrm{CBM}^{\mathrm{MQMW}}$ ), while the higher-molecular weight bands (indicated with $<$ ) are ribonuclease A ( $2 \mu \mathrm{g}$ per lane), which stays in solution over the full $\mathrm{pH}$ range.

with those of previous experiments showing the binding to be independent of $\mathrm{pH}$ in the range from 3 to $9 .{ }^{44}$ The indifference toward $\mathrm{pH}$ for all three variants of EXG demonstrates that none of the charged residues are vital for the binding of EXG:CBM to cellulose. These observations are consistent with previous results identifying the cellulose-binding site to mainly comprise residues $\operatorname{Trp} 17, \operatorname{Trp} 54$, and $\operatorname{Trp} 72$ and a few other potential hydrogen bonding residues in the vicinity of these. ${ }^{43}$
Charge Depletion of EXG:CBM Leaves the Protein Highly Soluble. Because previous studies report that charge depletion can inflict lowered protein solubility ${ }^{30}$ and increased precipitation rates, ${ }^{31}$ we examined these properties of the EXG:CBM variants. Following incubation of the proteins at concentrations of $7-10 \mathrm{mg} / \mathrm{mL}$ for a period of up to 2 weeks, we did not observe any precipitation, and the proteins remained stable at $\mathrm{pH} \mathrm{2,} \mathrm{7,} \mathrm{and} 12$ (Figure 3 and Figure S2).

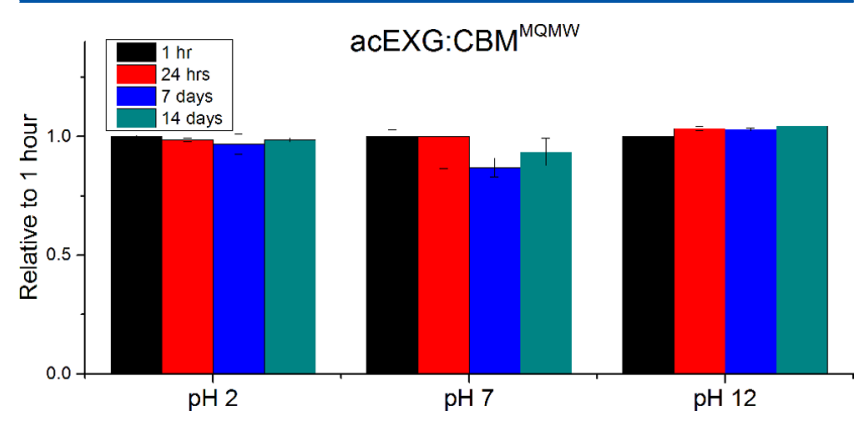

Figure 3. Precipitation propensity of acEXG:CBM ${ }^{\mathrm{MQMW}}$. The tendency of acEXG:CBM ${ }^{\mathrm{MQMW}}$ to precipitate out of solution under three different $\mathrm{pH}$ conditions was followed over time by high-speed centrifugation and measurement of the absorbance at $280 \mathrm{~nm}$. Measurements were performed in triplicate and normalized to the mean of the measurements at $1 \mathrm{~h}$. The initial protein concentrations were $7-10 \mathrm{mg} / \mathrm{mL}$.

Notably, even in the fully uncharged state, at $\mathrm{pH} \mathrm{2,}$ acEXG:CBM ${ }^{\mathrm{MQMW}}$ remains soluble and retains its cellulose binding functionality completely after 2 weeks (Figure S3). As such, neither the substitutions themselves nor the charge removal seems to have a substantial impact on protein functionality.

One of the observations from the cellulose binding assay was that the wild type and the EXG:CBM charge variants are readily precipitated by TCA (Figure 2 ). On the other hand, no sign of precipitation was observed even after extended periods of time in $50 \mathrm{mM}$ buffer (Figure 3). Still, we would expect the charge depletion to influence the equilibrium between the soluble and solid phase. All three proteins are highly soluble in MOPS buffer $(\geq 55 \mathrm{mg} / \mathrm{mL})$, so to assay differences in solubility, we used ammonium sulfate as a precipitant (Figure 4). The initial protein concentration did not have any impact on the measured solubility in the range of concentrations used for the experiments (Table S1, based on duplicate measurements).

As anticipated, ${ }^{14}$ solubility shows a close-to-logarithmic dependency on the ammonium sulfate concentration. While the slope is essentially the same, the solubility drops as a consequence of removing the four charged residues, with an additional decrease also related to removing the $\mathrm{N}$-terminal charge, even though the latter actually increases the overall net charge of the protein (from 0 in EXG:CBM ${ }^{\mathrm{MQMW}}$ to -1 in acEXG: $\mathrm{CBM}^{\mathrm{MQMW}}$ at $\mathrm{pH} 7$ ). Linear extrapolation of the data for EXG:CBM in Figure 4 to a salt-free solution results in an apparent solubility of $\approx 6 \mathrm{~g} / \mathrm{mL}$, but salting-in effects will probably level off the solubility at a lower ionic strength. Indeed, the data for EXG:CBM ${ }^{\mathrm{MQMW}}$ and acEXG:CBM ${ }^{\mathrm{MQMW}}$ do not seem to be strictly linear on a logarithmic scale at low salt concentrations. Experiments with polyethylene glycol (PEG) were conducted to obtain an extrapolated solubility in pure water, but we were not able to precipitate EXG:CBM with 


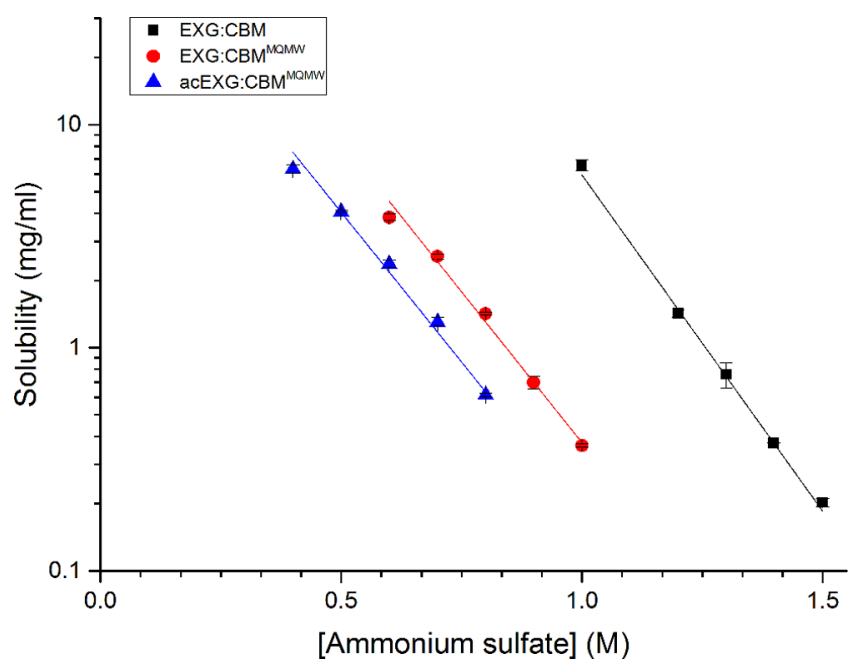

Figure 4. Ammonium sulfate precipitation of EXG:CBM, EXG:CBM ${ }^{\mathrm{MQMW}}$, and acEXG:CBM ${ }^{\mathrm{MQMW}}$. The protein solubility was measured in different concentrations of ammonium sulfate. The standard deviation of three independent measurements is shown. The lines show the best exponential fit. All measurements and preparations were performed at $\mathrm{pH} 7$ and $25{ }^{\circ} \mathrm{C}$.

up to $40 \%$ PEG 10000 and protein at concentrations as high as $20 \mathrm{mg} / \mathrm{mL}$ in $50 \mathrm{mM}$ MOPS.

How does EXG:CBM maintain solubility in the absence of charges? First, an intramolecular disulfide bond tethers the Nand C-termini, making aggregation by unfolding from the termini difficult. Second, the surface of EXG:CBM is rich in hydroxy amino acids (Ser and Thr), which occupy a third of the solvent accessible surface area. This is $\sim 3$ times more than in other well-studied, globular proteins (Table S2). Also amide residues (Asn and Gln) are abundant on the surface (Table S2), and this could explain why even the charge-modified variants can maintain such an unexpected high solubility $(\geq 55 \mathrm{mg} / \mathrm{mL})$. Interestingly, the three soluble proteins ( $\geq 100$ amino acids) in the PDB with only five or six charged residues (PDB entries $2 \mathrm{~K} 3 \mathrm{O}, 2 \mathrm{KHM}$, and $3 \mathrm{NDY}$ ) all have a similar abnormal abundance of hydroxy and amide amino acids on the surface (Table S2 and ref 46). This could also provide a plausible explanation for the low solubility observed for charge-free ubiquitin and protein $S 6 .{ }^{30,31}$ The surface of ubiquitin would be enriched with amide groups arising from the carbamylation of the positive residues but would still have a very low fraction of hydroxy groups compared to that of EXG:CBM. Even though all Lys and Arg residues are replaced with Ser in protein S6, the total surface area of hydroxy amino acids would still be only $16 \%$ in our simple analysis (Table S2). This is still only approximately half of what is seen in the natural weakly charged proteins. The effects of the introduction of hydroxy and amide residues on protein solubility have been tested experimentally, ${ }^{14,15}$ and although only a modest tendency to increase the solubility is seen, the introduction of such residues on a massive scale might effectively keep a protein soluble. If this is true, charge depletion of other weakly charged proteins, which contain a large fraction of hydroxy amino acids on their surface (Table S2), might also result in long-lived, soluble constructs.

The solubility of EXG:CBM ${ }^{\mathrm{MQMW}}$ was significantly affected by removing the positive $\mathrm{N}$-terminus (Figure 4). This appears to be in conflict with both the observation of the negligible effect of positive surface area on solubility ${ }^{16}$ and other studies showing that the positively charged amino and guanidino groups of lysine and arginine residues, respectively, are not able to increase the solubility of hydrophobic patches in proteins. $^{47,48}$ On the other hand, acEXG:CBM ${ }^{\mathrm{MQMW}}$ has a very low net charge $(-1$ at $\mathrm{pH} 7)$, and lysine residues have been shown to increase the solubility of proteins with a low or positive net charge. ${ }^{14,15}$ Further, it is possible that the small number of charges unmasks effects that are difficult to study in proteins with a greater number of charged residues. The observation that the solubility of all EXG:CBM variants was affected by the presence of ammonium sulfate (Figure 4) supports the current view that ammonium sulfate precipitation does not work by screening electrostatic protein interactions but rather by excluding water from the protein surface. ${ }^{49}$ Trichloroacetic acid (TCA) was also observed to efficiently precipitate both EXG:CBM and charge-modified variants (Figure 2) even though they are not sensitive to low $\mathrm{pH}$. The mechanism of TCA precipitation is still not fully understood, ${ }^{50}$ but our results indicate that the precipitating qualities of TCA are not solely linked to disruption of electrostatic interactions. Another result of practical relevance is the observation that the Coomassie staining efficiency of acEXG:CBM ${ }^{\mathrm{MQMW}}$ is reduced several-fold relative to that of EXG:CBM (Figure 2). This is most likely caused by the removal of positive charges. ${ }^{51,52}$

Stability and Structure Are Preserved in EXG:CBM ${ }^{\text {MQMW }}$ and acEXG:CBM ${ }^{\text {MQMW }}$. The thermodynamic stability of EXG:CBM, EXG:CBM ${ }^{M Q M W}$, and acEXG:CBM ${ }^{\mathrm{MQMW}}$ showed a cooperative denaturant-induced unfolding/refolding transition at both neutral $\mathrm{pH}$ and low $\mathrm{pH}$ (Figure 5 and Figure S5), which allowed us to determine

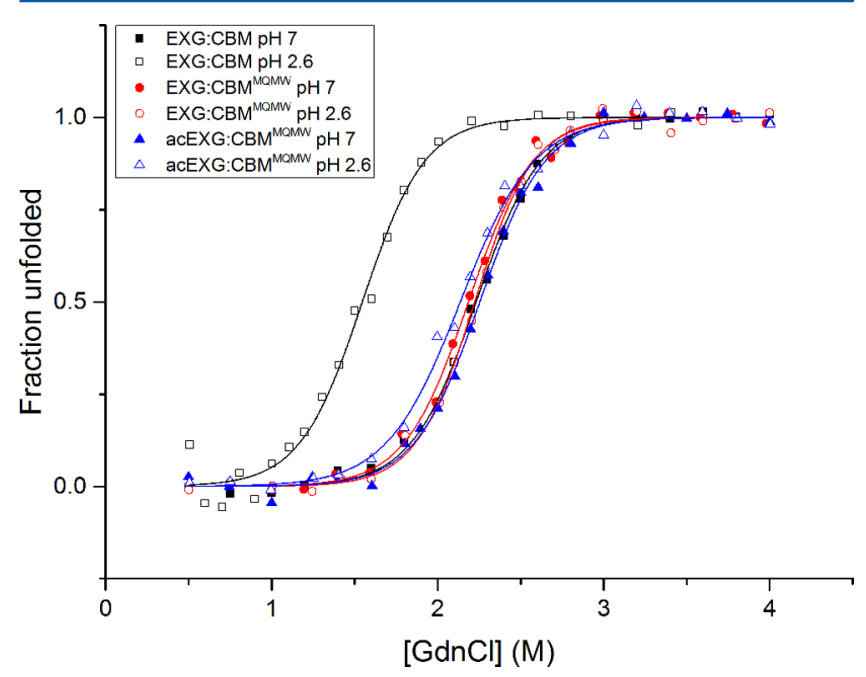

Figure 5. Chemical unfolding at neutral and low $\mathrm{pH}$ shows that stabilities are unaffected by charge state except for protonation of His90 in wild-type EXG:CBM. Protein unfolding was measured via the change in Trp fluorescence intensity. Solid lines represent fits using the linear extrapolation method ${ }^{56}$ normalized to the fraction of unfolded protein. A non-normalized version of the figure can be seen in Figure S5.

$\Delta G_{\mathrm{D}-\mathrm{N}}, C_{\mathrm{m}}$, and $m$ values (Table 1 ). The unfolding was in all cases fully reversible (Figure S4). We find that EXG:CBM is a relatively stable protein with an unfolding free energy at neutral $\mathrm{pH}\left(28 \mathrm{~kJ} \mathrm{~mol}^{-1}\right)$ that is comparable to those of many similarly sized proteins. $^{53}$

The stabilities of EXG:CBM ${ }^{\mathrm{MQMW}}$ and acEXG:CBM ${ }^{\mathrm{MQMW}}$ are within error the same as that of the parent protein at neutral 
Table 1. Parameters for Guanidine Hydrochloride-Induced Unfolding

\begin{tabular}{|c|c|c|c|c|c|c|}
\hline & \multicolumn{2}{|c|}{ EXG:CBM } & \multicolumn{2}{|c|}{ EXG:CBM ${ }^{\mathrm{MQMW}}$} & \multicolumn{2}{|c|}{ acEXG:CBM ${ }^{\mathrm{MQMW}}$} \\
\hline & pH 2.6 & $\mathrm{pH} 7$ & pH 2.6 & $\mathrm{pH} 7$ & pH 2.6 & pH 7 \\
\hline$m\left(\mathrm{~kJ} \mathrm{~mol}{ }^{-1} \mathrm{M}^{-1}\right)^{a}$ & $13.4 \pm 1.6$ & $12.7 \pm 0.7$ & $14.1 \pm 2.0$ & $12.9 \pm 0.5$ & $11.8 \pm 2.7$ & $13.0 \pm 1.1$ \\
\hline$C_{\mathrm{m}}(\mathrm{M})^{b}$ & $1.54 \pm 0.03$ & $2.23 \pm 0.04$ & $2.22 \pm 0.03$ & $2.18 \pm 0.00$ & $2.14 \pm 0.03$ & $2.25 \pm 0.00$ \\
\hline$\Delta G_{\mathrm{D}-\mathrm{N}}\left(\mathrm{kJ} \mathrm{mol}^{-1}\right)^{a}$ & $20.7 \pm 2.6$ & $28.3 \pm 1.1$ & $31.3 \pm 4.8$ & $28.2 \pm 1.0$ & $25.2 \pm 5.8$ & $29.3 \pm 2.5$ \\
\hline
\end{tabular}

${ }^{a}$ The $m$ value and $\Delta G_{\mathrm{D}-\mathrm{N}}$ were both obtained by fitting to the linear extrapolation method (see Experimental Procedures). The values presented here are the averages of several experiments, and their uncertainties represent the maximal deviations of the results of individual experiments from this average rather than the uncertainty from global fitting of the entire data set. ${ }^{b} C_{\mathrm{m}}$ was calculated from $m$ and $\Delta G_{\mathrm{D}-\mathrm{N}}$.

$\mathrm{pH}$, demonstrating that charge removal does not change the overall protein stability. Lowering the $\mathrm{pH}$ from 7.0 to 2.6 causes a decrease in the stability of EXG:CBM by $8 \pm 3 \mathrm{~kJ} \mathrm{~mol}^{-1}$, suggesting that the protonation of one or more residues [most likely H90 (see below)] decreases stability. In agreement with this suggestion, no such decrease was observed for EXG:CBM ${ }^{\mathrm{MQMW}}$ or acEXG:CBM ${ }^{\mathrm{MQMW}}$. The average magnitude of the $m$ value $\left(13 \mathrm{~kJ} \mathrm{~mol}^{-1} \mathrm{M}^{-1}\right.$ ) matches the expected value $\left(13.4 \pm 0.7 \mathrm{~kJ} \mathrm{~mol}^{-1} \mathrm{M}^{-1}\right)^{54}$ from unfolding a protein of 105 residues, the number of ordered residues in EXG:CBM. Thus, despite the unusual sequence composition and even after charge removal, the protein behaves like other proteins of the same size.

To study the impact of $\mathrm{pH}$ on protein structure more directly, we recorded a series of two-dimensional ${ }^{1} \mathrm{H}-{ }^{15} \mathrm{~N}$ HSQC NMR spectra as a function of $\mathrm{pH}$ for both EXG:CBM and EXG:CBM ${ }^{\mathrm{MQMW}}$. The spectra show that both proteins retain very similar three-dimensional structures over a broad pH interval (Figure 6 and Figures S6 and S7). Far- and near-

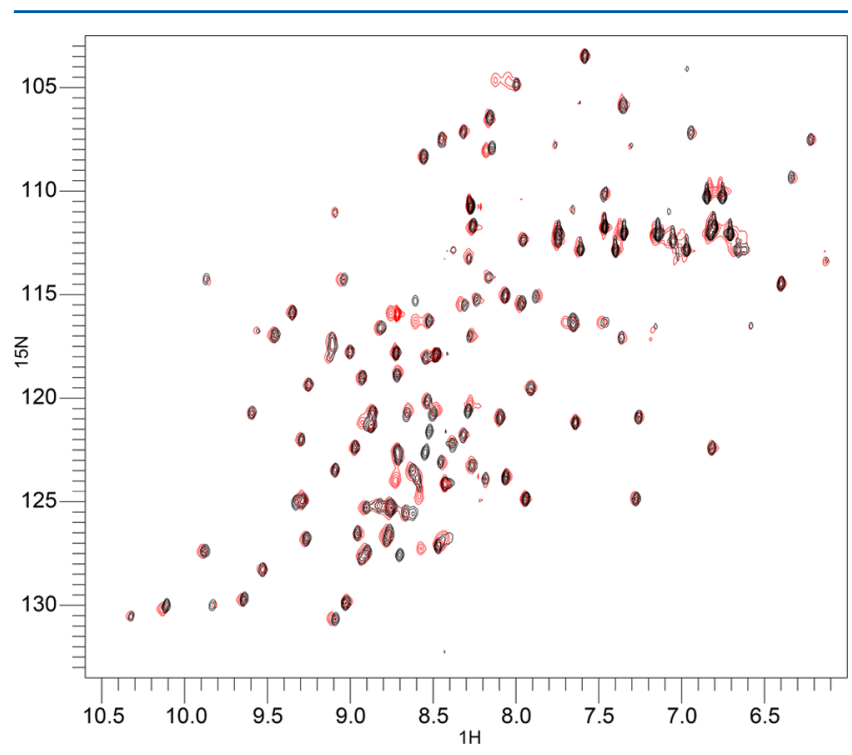

Figure 6. $\mathrm{EXG}: \mathrm{CBM}^{\mathrm{MQMW}}{ }^{15} \mathrm{~N}$ HMQC spectra at $\mathrm{pH} 1.8$ (red) and pH 6.3 (black).

UV circular dichroism (CD) data of acEXG:CBM ${ }^{\mathrm{MQMW}}$ at $\mathrm{pH}$ 2,7 , and 11 indicate that the secondary and tertiary structure of this variant is also unperturbed by the change in $\mathrm{pH}$ (Figure S8). The lack of $\mathrm{pH}$ sensitivity is unusual but is consistent with the notion that the charged residues of EXG are nonessential for the stability and function of this protein.

Effect of $\mathrm{pH}$ on Wild-Type and Charge-Neutral EXG:CBM Studied by NMR. Because the complexity of charge interactions is highly reduced, we were interested in studying protonation states in the EXG:CBM system. As NMR has previously been used to determine the structure of EXG:CBM, ${ }^{41}$ assignments of the wild-type HSQC spectra could be adopted directly. The five $\mathrm{N}$-terminal amino acids of the protein cannot be detected in the spectra and are thought to be unstructured. ${ }^{41}$ After assignment of the peaks, titration of EXG:CBM was conducted from $\mathrm{pH} 2$ to 9 in increments of $1 / 3$ $\mathrm{pH}$ unit. The protein clearly remains structured over the entire $\mathrm{pH}$ interval with only minor changes in the chemical shifts for most residues (Figure S6). However, the signal for H90 and several peaks from residues spatially close disappear between $\mathrm{pH} 3$ and 5, suggesting a conformational change or local adaptation to the protonation of $\mathrm{H} 90$ taking place with an intermediate exchange rate. Despite the small number of titratable residues in EXG:CBM, we were able to detect significant changes in more than half of the backbone amide chemical shifts. The simplicity of the system is, however, evident from the fact that all titration curves could be fitted well by a single Henderson-Hasselbalch equation (Figure S9). The $\mathrm{p} K_{\mathrm{a}}$ values of D36, H90, and the C-terminal G110 were found to be $4.2,4.0$, and 3.5 , respectively. The measured $\mathrm{p} K_{\mathrm{a}}$ value of H90 (4.0) is substantially shifted downward relative to the reference value $(6.5)$ in an alanine pentapeptide, ${ }^{55}$ suggesting that the protonation of this residue could be responsible for the destabilization of EXG:CBM observed at low $\mathrm{pH}$. This is further supported by the fact that the drop in stability is not observed in EXG:CBM ${ }^{\mathrm{MQMW}}$ or other mutants not containing the His residue. Because no chemical shift changes were observed above pH 6 for EXG:CBM (Figure S6), the titration of EXG:CBM ${ }^{\mathrm{MQMW}}$ was conducted from $\mathrm{pH} 1.8$ to 6.2. The resulting spectra clearly demonstrated the persistence of the protein toward changes in $\mathrm{pH}$ (Figure 6). Only very few changes in chemical shifts are evident, all of which fitted to the Henderson-Hasselbalch equation and is consistent with titration of the C-terminus with a $\mathrm{p} K_{\mathrm{a}}$ of $3.7 \pm 0.2$ (Figure $\mathrm{S} 10$ ). The inertness of the protein to $\mathrm{pH}$ might in part be sustained by its unstructured $\mathrm{N}$-terminus, giving the $\mathrm{N}$-terminal charge only little uniform effect on the rest of the protein (much like a free ion). In fact, not a single peak in the EXG:CBM HSQC experiments (Figure S9) is significantly affected by the presumed protonation of the $\mathrm{N}$-terminus $\left(\mathrm{p} K_{\mathrm{a}}\right.$ $\sim 8$ ) in the $\mathrm{pH}$ interval between 6 and 9. Taken together, these data clearly indicate that changing the $\mathrm{pH}$ has an only limited impact on the structure of EXG:CBM ${ }^{\mathrm{MQMW}}$.

\section{CONCLUDING REMARKS}

We have demonstrated that the charge-minimized protein EXG:CBM ${ }^{\mathrm{MQMW}}$ is folded and functional as judged by several criteria. (i) It is capable of high-affinity cellulose binding. (ii) It has a well-defined folding transition similar in shape and stability to that of the wild type. (iii) NMR spectra are well dispersed and similar to that of the wild type. (iv) Its solubility 
is surprisingly high (at least $55 \mathrm{mg} / \mathrm{mL}$ ), and it does not have any tendency to precipitate over extended periods of time. These results also apply to the acetylated form of the mutant protein. While previous reports of charge-free proteins depend heavily on low $\mathrm{pH}$ to be uncharged, ${ }^{30,31}$ our study is, to the best of our knowledge, the first to show a fully functional protein completely free of titratable side chains. It demonstrates that while charged residues in many cases do aid the in vivo folding and solubility of proteins, they are not an absolute prerequisite. The existence of charge-depleted EXG:CBM ${ }^{\mathrm{MQMW}}$ therefore adds to our understanding of what is achievable with protein design, and we envisage that this protein can be useful in helping elucidate detailed electrostatic properties in proteins.

\section{ASSOCIATED CONTENT}

\section{S Supporting Information}

The Supporting Information is available free of charge on the ACS Publications website at DOI: 10.1021/acs.biochem.6b00269.

Multiple-sequence aligment of family 2 CBMs, precipitation propensity of EXG:CBM and EXG:CBM ${ }^{\mathrm{MQMW}}$, cellulose binding assay, guanidine hydrochloride undfolding curves, far- and near-UV CD of acEXG:CBM ${ }^{\mathrm{MQMW}}$, ${ }^{1} \mathrm{H}-{ }^{15} \mathrm{~N}$ HSQC spectra of EXG:CBM, titration curves, and Tables S1 and S2 (PDF)

\section{AUTHOR INFORMATION}

\section{Corresponding Author}

*Phone: +45 3532 1500. E-mail: jrwinther@bio.ku.dk.

\section{Present Addresses}

${ }^{\dagger}$ C.K.: Center for Evolutionary Chemical Biology, Department of Chemistry, University of Copenhagen, DK-2200 Copenhagen N, Denmark.

${ }^{*}$ R.E.: Section for Protein Sciences, Department of Systems Biology, Technical University of Denmark, DK-2800 Kgs. Lyngby, Denmark.

${ }^{\S}$ K.E.J.: Section of Pharmaceutical Technology and Engineering, Department of Pharmacy, University of Copenhagen, DK2100 Copenhagen $\varnothing$, Denmark.

"M.V.: Institute of Theoretical Physics, University of Cologne, 50937 Köln, Germany.

\section{Author Contributions}

C.H., C.K., and R.E. contributed equally to this work.

\section{Funding}

The project was funded in part by Grant NNF12OC0000793 from the Novonordisk foundation to J.R.W. and Grant 09070508 from the Danish Council for Independent Research, Technology and Production Sciences (FTP) to M.W.

\section{Notes}

The authors declare no competing financial interest.

\section{ABBREVIATIONS}

CD, circular dichroism; PDB, Protein Data Bank; PEG, polyethylene glycol; TCA, trichloroacetic acid.

\section{ADDITIONAL NOTES}

${ }^{a}$ We will throughout the text use the term "charged residues" to refer to the titratable residues.

${ }^{b}$ UniProtKB/Swiss-Prot protein knowledgebase release 2015_09 statistics.

\section{REFERENCES}

(1) Sheinerman, F. B., Norel, R., and Honig, B. (2000) Electrostatic aspects of protein-protein interactions. Curr. Opin. Struct. Biol. 10, 153-159.

(2) Brock, K., Talley, K., Coley, K., Kundrotas, P., and Alexov, E. (2007) Optimization of electrostatic interactions in protein-protein complexes. Biophys. J. 93, 3340-3352.

(3) Lawrence, M. S., Phillips, K. J., and Liu, D. R. (2007) Supercharging proteins can impart unusual resilience. J. Am. Chem. Soc. 129, 10110-10112.

(4) Miklos, A. E., Kluwe, C., Der, B. S., Pai, S., Sircar, A., Hughes, R. A., Berrondo, M., Xu, J., Codrea, V., Buckley, P. E., Calm, A. M., Welsh, H. S., Warner, C. R., Zacharko, M. A., Carney, J. P., Gray, J. J., Georgiou, G., Kuhlman, B., and Ellington, A. D. (2012) Structurebased design of supercharged, highly thermoresistant antibodies. Chem. Biol. 19, 449-455.

(5) Simeonov, P., Berger-Hoffmann, R., Hoffmann, R., Strater, N., and Zuchner, T. (2011) Surface supercharged human enteropeptidase light chain shows improved solubility and refolding yield. Protein Eng., Des. Sel. 24, 261-268.

(6) Xiao, L., and Honig, B. (1999) Electrostatic contributions to the stability of hyperthermophilic proteins. J. Mol. Biol. 289, 1435-1444.

(7) Zhou, X. X., Wang, Y. B., Pan, Y. J., and Li, W. F. (2008) Differences in amino acids composition and coupling patterns between mesophilic and thermophilic proteins. Amino Acids 34, 25-33.

(8) Yokota, K., Satou, K., and Ohki, S. (2006) Comparative analysis of protein thermo stability: Differences in amino acid content and substitution at the surfaces and in the core regions of thermophilic and mesophilic proteins. Sci. Technol. Adv. Mater. 7, 255-262.

(9) Jeppesen, M. D., Westh, P., and Otzen, D. E. (2010) The role of protonation in protein fibrillation. FEBS Lett. 584, 780-784.

(10) Morshedi, D., Ebrahim-Habibi, A., Moosavi-Movahedi, A. A., and Nemat-Gorgani, M. (2010) Chemical modification of lysine residues in lysozyme may dramatically influence its amyloid fibrillation. Biochim. Biophys. Acta, Proteins Proteomics 1804, 714-722.

(11) Es-haghi, A., Shariatizi, S., Ebrahim-Habibi, A., and NematGorgani, M. (2012) Amyloid fibrillation in native and chemicallymodified forms of carbonic anhydrase II: Role of surface hydrophobicity. Biochim. Biophys. Acta, Proteins Proteomics 1824, 468-477.

(12) Chiti, F., Stefani, M., Taddei, N., Ramponi, G., and Dobson, C. M. (2003) Rationalization of the effects of mutations on peptide and protein aggregation rates. Nature 424, 805-808.

(13) Shaw, B. F., Moustakas, D. T., Whitelegge, J. P., and Faull, K. F. (2010) Taking Charge of Proteins: From Neurodegeneration to Industrial Biotechnology. Adv. Protein Chem. Struct. Biol. 79, 127-164.

(14) Trevino, S. R., Scholtz, J. M., and Pace, C. N. (2007) Amino acid contribution to protein solubility: Asp, Glu, and Ser contribute more favorably than the other hydrophilic amino acids in RNase Sa. J. Mol. Biol. 366, 449-460.

(15) Islam, M. M., Khan, M. A., and Kuroda, Y. (2012) Analysis of amino acid contributions to protein solubility using short peptide tags fused to a simplified BPTI variant. Biochim. Biophys. Acta, Proteins Proteomics 1824, 1144-1150.

(16) Kramer, R. M., Shende, V. R., Motl, N., Pace, C. N., and Scholtz, J. M. (2012) Toward a molecular understanding of protein solubility: increased negative surface charge correlates with increased solubility. Biophys. J. 102, 1907-1915.

(17) Collins, K. D. (1997) Charge density-dependent strength of hydration and biological structure. Biophys. J. 72, 65-76.

(18) Horovitz, A., Serrano, L., Avron, B., Bycroft, M., and Fersht, A. R. (1990) Strength and co-operativity of contributions of surface salt bridges to protein stability. J. Mol. Biol. 216, 1031-1044.

(19) Xiao, S., Patsalo, V., Shan, B., Bi, Y., Green, D. F., and Raleigh, D. P. (2013) Rational modification of protein stability by targeting surface sites leads to complicated results. Proc. Natl. Acad. Sci. U. S. A. 110, 11337-11342.

(20) Sali, D., Bycroft, M., and Fersht, A. R. (1991) Surface electrostatic interactions contribute little of stability of barnase. J. Mol. Biol. 220, 779-788. 
(21) Gribenko, A. V., Patel, M. M., Liu, J., McCallum, S. A., Wang, C., and Makhatadze, G. I. (2009) Rational stabilization of enzymes by computational redesign of surface charge-charge interactions. Proc. Natl. Acad. Sci. U. S. A. 106, 2601-2606.

(22) Arnold, U., and Schopfel, M. (2012) Significant stabilization of ribonuclease A by additive effects. FEBS J. 279, 2508-2519.

(23) Takano, K., Tsuchimori, K., Yamagata, Y., and Yutani, K. (2000) Contribution of salt bridges near the surface of a protein to the conformational stability. Biochemistry 39, 12375-12381.

(24) Makhatadze, G. I., Loladze, V. V., Ermolenko, D. N., Chen, X., and Thomas, S. T. (2003) Contribution of surface salt bridges to protein stability: guidelines for protein engineering. J. Mol. Biol. 327, $1135-1148$.

(25) Donald, J. E., Kulp, D. W., and DeGrado, W. F. (2011) Salt bridges: geometrically specific, designable interactions. Proteins: Struct., Funct., Genet. 79, 898-915.

(26) Webb, H., Tynan-Connolly, B. M., Lee, G. M., Farrell, D., O'Meara, F., Sondergaard, C. R., Teilum, K., Hewage, C., McIntosh, L. P., and Nielsen, J. E. (2011) Remeasuring HEWL pK(a) values by NMR spectroscopy: methods, analysis, accuracy, and implications for theoretical pK(a) calculations. Proteins: Struct., Funct., Genet. 79, 685702.

(27) Farrell, D., Miranda, E. S., Webb, H., Georgi, N., Crowley, P. B., McIntosh, L. P., and Nielsen, J. E. (2010) Titration_DB: storage and analysis of NMR-monitored protein $\mathrm{pH}$ titration curves. Proteins: Struct., Funct., Genet. 78, 843-857.

(28) Gosink, L. J., Hogan, E. A., Pulsipher, T. C., and Baker, N. A. (2014) Bayesian model aggregation for ensemble-based estimates of protein $\mathrm{pK}(\mathrm{a})$ values. Proteins: Struct., Funct., Genet. 82, 354-363.

(29) Nielsen, J. E., Gunner, M. R., and García-Moreno E, B. (2011) The $\mathrm{pK}(\mathrm{a})$ Cooperative: A collaborative effort to advance structurebased calculations of $\mathrm{pK}(\mathrm{a})$ values and electrostatic effects in proteins. Proteins: Struct., Funct., Genet. 79, 3249-3259.

(30) Loladze, V. V., and Makhatadze, G. I. (2002) Removal of surface charge-charge interactions from ubiquitin leaves the protein folded and very stable. Protein Sci. 11, 174-177.

(31) Kurnik, M., Hedberg, L., Danielsson, J., and Oliveberg, M. (2012) Folding without charges. Proc. Natl. Acad. Sci. U. S. A. 109, 5705-5710.

(32) Kamtekar, S., Schiffer, J. M., Xiong, H., Babik, J. M., and Hecht, M. H. (1993) Protein design by binary patterning of polar and nonpolar amino acids. Science 262, 1680-1685.

(33) Riddle, D. S., Santiago, J. V., Bray-Hall, S. T., Doshi, N., Grantcharova, V. P., Yi, Q., and Baker, D. (1997) Functional rapidly folding proteins from simplified amino acid sequences. Nat. Struct. Biol. 4, 805-809.

(34) Akanuma, S., Kigawa, T., and Yokoyama, S. (2002) Combinatorial mutagenesis to restrict amino acid usage in an enzyme to a reduced set. Proc. Natl. Acad. Sci. U. S. A. 99, 13549-13553.

(35) Walter, K. U., Vamvaca, K., and Hilvert, D. (2005) An active enzyme constructed from a 9-amino acid alphabet. J. Biol. Chem. 280, 37742-37746.

(36) Schymkowitz, J., Borg, J., Stricher, F., Nys, R., Rousseau, F., and Serrano, L. (2005) The FoldX web server: an online force field. Nucleic Acids Res. 33, W382-388.

(37) Knudsen, K. B., Kofoed, C., Espersen, R., Hojgaard, C., Winther, J. R., Willemoes, M., Wedin, I., Nuopponen, M., Vilske, S., Aimonen, K., Weydahl, I. E., Alenius, H., Norppa, H., Wolff, H., Wallin, H., and Vogel, U. (2015) Visualization of Nanofibrillar Cellulose in Biological Tissues Using a Biotinylated Carbohydrate Binding Module of beta1,4-Glycanase. Chem. Res. Toxicol. 28, 1627-1635.

(38) Schagger, H. (2006) Tricine-SDS-PAGE. Nat. Protoc. 1, 16-22.

(39) Walker, J. M. (2005) The proteomics protocols handbook, Humana Press, Totowa, NJ.

(40) Lian, L.-Y., and Roberts, G. C. K. (2011) Protein NMR spectroscopy: practical techniques and applications, Wiley, Chichester, U.K.

(41) Xu, G. Y., Ong, E., Gilkes, N. R., Kilburn, D. G., Muhandiram, D. R., Harrisbrandts, M., Carver, J. P., Kay, L. E., and Harvey, T. S.
(1995) Solution Structure of a Cellulose-Binding Domain from Cellulomonas-Fimi by Nuclear-Magnetic-Resonance Spectroscopy. Biochemistry 34, 6993-7009.

(42) Fraczkiewicz, R, and Braun, W. (1998) Exact and efficient analytical calculation of the accessible surface areas and their gradients for macromolecules. J. Comput. Chem. 19, 319-333.

(43) McLean, B. W., Bray, M. R., Boraston, A. B., Gilkes, N. R., Haynes, C. A., and Kilburn, D. G. (2000) Analysis of binding of the family 2a carbohydrate-binding module from Cellulomonas fimi xylanase 10A to cellulose: specificity and identification of functionally important amino acid residues. Protein Eng., Des. Sel. 13, 801-809.

(44) Ong, E., Gilkes, N. R., Miller, R. C., Warren, R. A. J., and Kilburn, D. G. (1993) The Cellulose-Binding Domain (Cbdcex) of an Exoglucanase from Cellulomonas-Fimi - Production in EscherichiaColi and Characterization of the Polypeptide. Biotechnol. Bioeng. 42, 401-409.

(45) Jervis, E. J., Haynes, C. A., and Kilburn, D. G. (1997) Surface diffusion of cellulases and their isolated binding domains on cellulose. J. Biol. Chem. 272, 24016-24023.

(46) Hagn, F., Eisoldt, L., Hardy, J. G., Vendrely, C., Coles, M., Scheibel, T., and Kessler, H. (2010) A conserved spider silk domain acts as a molecular switch that controls fibre assembly. Nature 465, 239-U131.

(47) Chan, P., Curtis, R. A., and Warwicker, J. (2013) Soluble expression of proteins correlates with a lack of positively-charged surface. Sci. Rep. 3, 3333 DOI: 10.1038/srep03333.

(48) Yagi, S., Akanuma, S., and Yamagishi, A. (2014) Addition of negatively charged residues can reverse the decrease in the solubility of an acidic protein caused by an artificially introduced non-polar surface patch. Biochim. Biophys. Acta, Proteins Proteomics 1844, 553-560.

(49) Wingfield, P. (2001) Protein Precipitation Using Ammonium Sulfate. In Current Protocols in Protein Science, John Wiley \& Sons, Inc., New York.

(50) Rajalingam, D., Loftis, C., Xu, J. J., and Kumar, T. K. (2009) Trichloroacetic acid-induced protein precipitation involves the reversible association of a stable partially structured intermediate. Protein Sci. 18, 980-993.

(51) de Moreno, M. R., Smith, J. F., and Smith, R. V. (1986) Mechanism studies of coomassie blue and silver staining of proteins. $J$. Pharm. Sci. 75, 907-911.

(52) Tal, M., Silberstein, A., and Nusser, E. (1985) Why Does Coomassie Brilliant Blue-R Interact Differently with Different Proteins - a Partial Answer. J. Biol. Chem. 260, 9976-9980.

(53) Maxwell, K. L., Wildes, D., Zarrine-Afsar, A., De Los Rios, M. A., Brown, A. G., Friel, C. T., Hedberg, L., Horng, J. C., Bona, D., Miller, E. J., Vallee-Belisle, A., Main, E. R., Bemporad, F., Qiu, L., Teilum, K., Vu, N. D., Edwards, A. M., Ruczinski, I., Poulsen, F. M., Kragelund, B. B., Michnick, S. W., Chiti, F., Bai, Y., Hagen, S. J., Serrano, L., Oliveberg, M., Raleigh, D. P., Wittung-Stafshede, P., Radford, S. E., Jackson, S. E., Sosnick, T. R., Marqusee, S., Davidson, A. R., and Plaxco, K. W. (2005) Protein folding: defining a "standard" set of experimental conditions and a preliminary kinetic data set of two-state proteins. Protein Sci. 14, 602-616.

(54) Geierhaas, C. D., Nickson, A. A., Lindorff-Larsen, K., Clarke, J., and Vendruscolo, M. (2006) BPPred: a Web-based computational tool for predicting biophysical parameters of proteins. Protein Sci. 16, 125134.

(55) Thurlkill, R. L., Grimsley, G. R., Scholtz, J. M., and Pace, C. N. (2006) $\mathrm{pK}$ values of the ionizable groups of proteins. Protein Sci. 15, 1214-1218.

(56) Santoro, M. M., and Bolen, D. W. (1988) Unfolding free energy changes determined by the linear extrapolation method. 1. Unfolding of phenylmethanesulfonyl alpha-chymotrypsin using different denaturants. Biochemistry 27, 8063-8068. 